\title{
How coastal development, environmental change, and adaptive behavior affects fishermen's welfare?: (A Study of Traditional Fishermen from the Coastal Area of Manado Bay, Indonesia)
}

\author{
Daisy.I.E Sundah ${ }^{1}$, Agus Suman ${ }^{2}$, Soemarno ${ }^{3}$, Paulus Kindangen ${ }^{4}$ \\ ${ }^{1}$ Graduate Program of Environmental Science and Technology, The University of Brawijaya, Malang, \\ Indonesia, and The Department of Business Management, Manado State Polytechnic, Manado,Indonesia. \\ ${ }^{2}$ Faculty of Economics, The University of Brawijaya, Malang, Indonesia \\ ${ }^{3}$ Faculty of Agriculture, The University of Brawijaya, Malang, Indonesia, and \\ ${ }^{4}$ Faculty of Economics, The University of Sam Ratulangi, Manado, Indonesia .
}

\begin{abstract}
Coastal development, change in the fishermen's environment, and adaptations in their behaviour affects the welfare of traditional fishermen in the coastal area of Manado Bay, North Sulawesi Indonesia. This study determines, both partially and simultaneously, directly and indirectly, totally, the extent and the influence of coastal development, the change in environment and the adaptation of behaviour on the welfare of traditional Manadonese fishermen. This study's methodology uses the mixed method by integrating the quantitative and qualitative approaches. Probability sampling has been used in collecting data from as many as 125 fishermen from Bunaken, Tuminting, Wenang, Sario, and Malalayang districts of the coastal area of Manado Bay. Moreover, Structural Equation Modelling (SEM) has been used in analysing the data of this study. The result shows that coastal development, change in fishermen's environment, and the adaptation of their behaviour influence both positively and significantly the welfare of traditional Manadonese fishermen and either partially or simultaneously, directly or indirectly, and totally.
\end{abstract}

Keywords: Coastal economy, environmental change, human behavior, fishermen's welfare, dan Structural Equation Modeling (SEM).

\section{INTRODUCTION}

Poverty reduction becomes the crucial agendas for many developing countries. It is principally important in coastal area where natural resources abundance but coastal dwellers still in poverty. Throughout the world, coastal is fragile habitat and development programs significantly affect coastal live systems. In coastal area, scholar argues that development should be meet environmental conservation [1] [2] [3]. In line with such issues, Indonesia has designed a development strategy that is focused on increasing economic growth while in the same time promoting environmental conservation as a basic principles of sustainable development [4] [5].

Indonesian national development planning pays a lot of attention to reduce poverty and increase welfare of the community. According to Indonesian government welfare was defined as a condition where material, spiritual, and socials need of citizens to the standard of live was met. Development is one of the key to achieve society welfare. While development able to increase economic indicator in many areas, development likely changes physical environment and human behavior [6]. Physical and social environmental change provides significant impact to human adaptation. Psychologically, adaptation is the human effort to modify themselves to the physical and social change by developing adaptive patterns. It is including strategic change in livelihood [7].

In the reality, there is a prevailing paradox in the development implementation in the coastal area. Recently, local government has the attempted to speed up the development in the area and this has unfavorably influenced the sustainability of the environment and the natural resources in the coastal and adjacent regions. For example, unfavorable consequences have included the development of slum areas, social gaps, pollution, erosion, physical degradation of important habitats, over exploitation of resources, and conflict over land and resources usage, which finally threatens the sustainability of the environment in the coastal area [1] [2].

Manado is one of the coastal district area in North Sulawesi Province whit rapid urbanization and economic development. Tourism is one of the significant factor for coastal development in Manado Bay area [8]. Based on observation of the coastal area of Manado Bay, especially at the Boulevard on Business (BOB), which has become a developed new urban area characterized by economic activities supported by various modern and sophisticated facilities. Development, however, seems to be provides minimal benefits for local people. For instance, outsider benefited from coastal tourism development, but local people were few involved [9]. Moreover, the statistics data show that the society from the coastal area in Manado Bay has been categorized as very poor $(10 \%)$, poor $(28 \%)$, and almost poor $(62 \%)$ [10]. In the context of fishermen's 
adaptation to live in recent rapid development, fishermen have changed their professions by adopting other promising commercial opportunities. They have experienced income improvement through participation in various businesses, such as: shops, stalls, restaurants, and other businesses that has a tendency to enhance the quality of people's life.

The article has two objectives. The first is to determine the influence of costal development, environmental change, and adaptive behavior of the traditional Manadonese fishermen's to welfare. Secondly, the paper aims to perform the model of the relationship between the variables of the development, environmental change, and the adaptive behavior with the traditional fishermen's welfare.

\section{METHODOLOGY}

\section{Study area}

The study was carried out at five locations in Manado coastal area namely: Malalayang, Sario, Wenang, Tuminting, and Bunaken districts. This area plays an important role in north Sulawesi economic activity. There are Mega Mall shopping centers, Manado Town Square (ManTos), Bahu Mall, Manado Trade Center (MTC), Information Technology Center (ITC), restaurant, Siloam Hospital, Fish Auction Place, Harbor, Traditional Market, Office complex, and residential areas established in coastal area. Among such study area, Bunaken district is a conservation area which is protected by the Indonesian government which seeks to protect the biodiversity of corals at Bunaken Island. Bunaken was also become the famous nature-based tourism destination in North Sulawesi [8]. There are five rivers with estuaries in the coastal area of Manado Bay encompasess Tondano River (11 Km); Bailang River (17,9 Km); Sario River (6,72 Km); Malalayang River (4,80 Km); and Tikala River (7,12 Km) [10]. Urbanization has been grown since 1980's and lead several changes in land uses, economic structure and social aspect of coastal community. While urbanization grows rapidly, some coastal community is traditional fishermen who catch fish using traditional and semi-modern boats individually or in group using simple equipment. The research location is shown in the Figure 1:

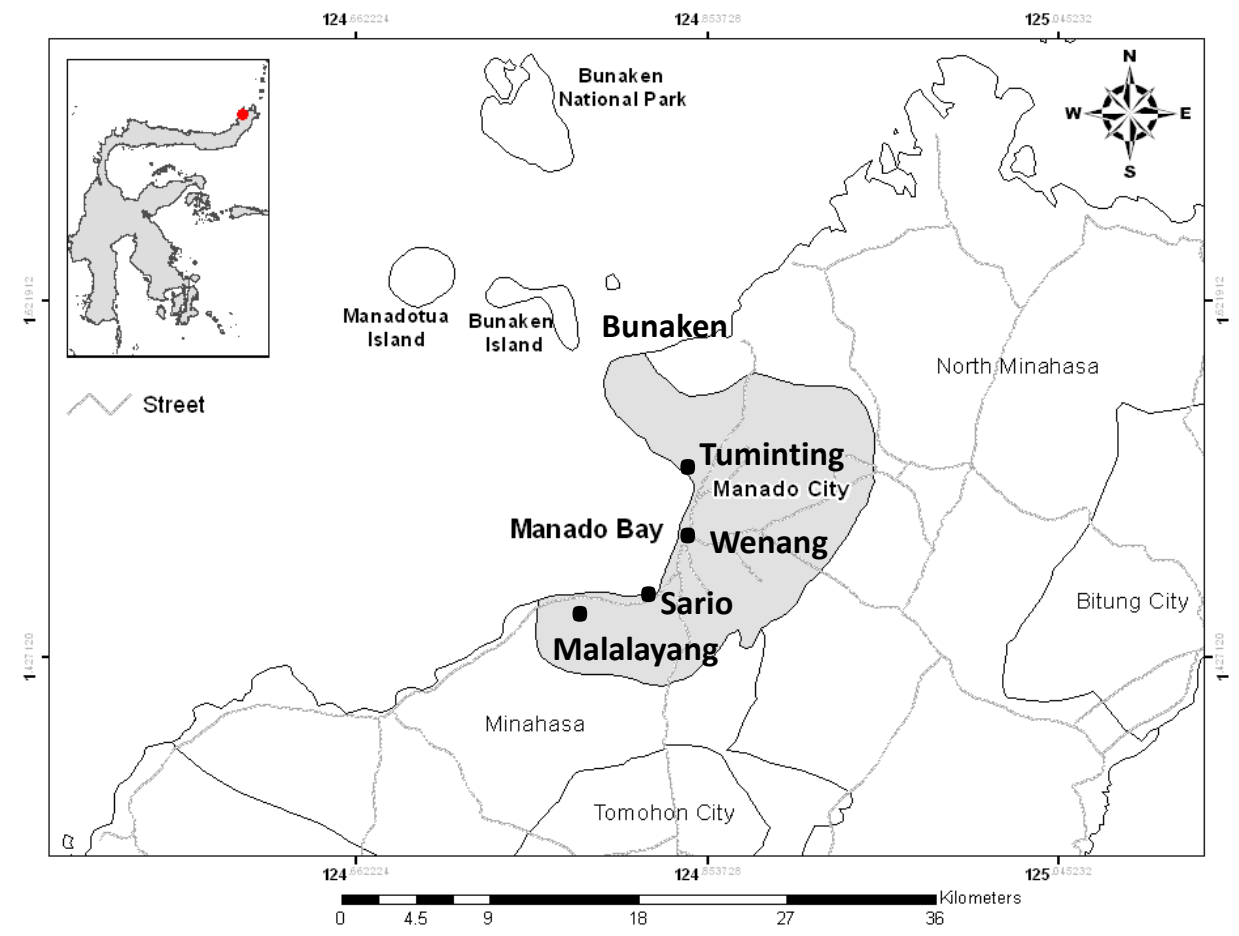

Fig. 1. Geographical Location at Coastal Area of Manado Bay, Manado City, North Sulawesi Province, Indonesia.

\section{Methods}

The methodology used in this research simultaneously integrates the quantitative and qualitative methods. This model combines two different ways of collecting and analyzing data from quantitative in the first step and qualitative at the second step. Field researches were conducted at August to September 2012 by distributing the questionnaire to respondents and perform structured interviews to particular fishermen. The respondent consists of traditional fishermen in the coastal area of Manado Bay. About 25 respondents were selected randomly from each village. Totally, there are 125 respondent was involved in this study. Technically, such sample size is considered sufficient for the minimum standard in Structural Equation Modeling (SEM). 
These respondents are selected from those fishermen who have been involved in traditional fishing for 20 to 37 years.

Among 125 fishermen, some of them were selected to be involved in structured interviews. The structured interviews were perform to probe the level of knowledge, attitude, and in-depth views of the fishermen on development in coastal area, environment, adaptive behavior and welfare.

The Quantitative data was then tabulated and analyzed using AMOS 20 software. The obtained results from the structural equation modeling analysis is then interpreted and analyzed in the form of tables, figures, and in conjunction with the qualitative data. The qualitative data from the interviews was collected and organized into interview's lists for further descriptive analysis. Every individual answer obtained from the respondent is thoroughly reviewed until overall a comprehensive level of understanding is achieved.

\section{III.}

A General Picture of the Respondents

\section{RESULT AND DisCUSSION}

Of the sample of 125 respondents based on their age, most of the respondents are 22 to 56 years old (84.6\%) in conducting their profession as the fishermen, whilst the oldest respondents are 54-77 years old (3.2\%). Mostly the respondents state that their work as fishermen is a hobby, and therefore the respondent states that their age does not limit them to do the job of fishermen. Mostly respondents have low educational backgrounds. Moreover, the respondents who have not graduated from elementary school or never went to school, total 65 persons, or $52 \%$ of the sample of 125 and only a few respondents $(1.6 \%)$ have higher education. This indicates that these traditional fishermen have a low capability in entering into the market and workplace in the coastal area of Manado Bay.

The interview results indicated that their reason for not attending school or continuing onto higher education, was essentially because of economic inability. Moreover, they feel they are able to earn money more quickly by catching fish compared to attending school, as stated by some respondents as follows:

"because our parents unable to fund my school, then it is the time for fish season, we like to follow our fathers to catch fish in the sea, or together with other children, we ask for fishes from other fishermen, then sell the fish for money. So, it is proper if we cannot get remove class and finally do not attend the school anymore".

Moreover, the research found that most of the respondents (64\%) have done the job as fishermen for $20-37$ years, and even $21 \%$ has done it for 38-55 years. It indicates that most of the respondents have done the job from their childhood and adolescence. It was because they followed their parents as the fishermen from generation to generation.

\section{Some Assumptions of Structural Equation Modeling (SEM)}

There are some basic requirements in the structural equation modeling (SEM), that is data normality, singularity test, and multi co-linearity, and outlier have been fulfilled. The data normality test shows that the research data are distributed normally, either univariate or multivariate, because the critical ratio of 1.061 is between the $-1.96<$ critical ratio $<+1.96$. The singularity and multi co-linearity tests show that there were no singularity and multi co-linearity problems to the tested variables. It was found that the determinant of sample covariance matrix of 0.042 almost approached to zero. Finally, the outlier test shows that there was no emerging data with extreme values in the research. Therefore, it can be concluded that the results of the structural equation modeling (SEM) can be continued further to the other SEM process.

\section{The Validity Test of the Measurement Model}

The structural equation modeling has been tested and it is appropriate for the sample data. It was tested through the test of absolute fit indices, the incremental fit indices, and parsimony fit indices (Table 1). The testing results with a total of 15 criteria of testing instruments shows that coastal development, environmental change, and adaptive behavior as influences on the traditional fishermen's welfare are "fit" or suitable with the collected data.

Table 1. Goodness of fit test

\begin{tabular}{|c|c|c|c|c|c|}
\hline $\mathrm{NO}$ & $\begin{array}{l}\text { Testing } \\
\text { Group }\end{array}$ & Testing Instruments & $\begin{array}{c}\text { Values Criteria } \\
\text { Cut - Off (Standard) }\end{array}$ & $\begin{array}{l}\text { Results of } \\
\text { AMOS } 20 \\
\end{array}$ & Explanation \\
\hline \multirow{3}{*}{1} & \multirow{3}{*}{$\begin{array}{l}\text { Absolute } \\
\text { Fit Indices }\end{array}$} & Chi-Square & $\begin{array}{l}\text { Between Chi-Square } \\
\text { Minimum (CMIN) } \\
\text { 'saturated model' \& } \\
\text { CMIN Independence }\end{array}$ & 88,946 & $\begin{array}{l}\text { Model 'fit' } \\
\text { Chi-Square }\left(\mathrm{X}^{2}\right) \text { with degree } \\
\text { of freedom }(\mathrm{df})=71\end{array}$ \\
\hline & & Goodness of Fit (GFI) & $\begin{array}{l}\text { The nearer to } 1 \\
\text { Model 'fit' the better }\end{array}$ & 0,906 & Model 'fit' \\
\hline & & $\begin{array}{l}\text { Adjusted Godness of Fit' } \\
\text { (AGFI) }\end{array}$ & $\begin{array}{l}\text { The nearer to } 1 \\
\text { Model 'fit' the better }\end{array}$ & 0,862 & Model 'fit' \\
\hline
\end{tabular}


How coastal development, environmental change, and adaptive behavior affects fishermen's

\begin{tabular}{|c|c|c|c|c|c|}
\hline & & Root Mean Residual(RMR) & Expected be small & 0,072 & Model 'fit' \\
\hline \multirow{5}{*}{2} & \multirow{5}{*}{$\begin{array}{l}\text { Incremental } \\
\text { Fit Indices }\end{array}$} & Normed Fit Index (NFI) & \multirow{5}{*}{$\begin{array}{l}4 \text { from } 5 \text { testing } \\
\text { instrument of the } \\
\text { incremental fit index has } \\
\text { same range value from } 0 \\
\text { to } 1 .\end{array}$} & 0,910 & \multirow{5}{*}{$\begin{array}{l}\text { Model 'fit } \\
\text { (Calculation value between } 0 \\
\text { to } 1 \text { and } 4 \text { testing instruments } \\
\text { have same range value }>0.9 \text { ) }\end{array}$} \\
\hline & & Comparative Fit Index (CFI) & & 0,980 & \\
\hline & & Incremental Fit Index (IFI) & & 0,981 & \\
\hline & & Rho Fit Index (RFI) & & 0,885 & \\
\hline & & Tucker Lewis Index (TLI) & & 0,974 & \\
\hline \multirow{7}{*}{3} & \multirow{7}{*}{$\begin{array}{l}\text { Parsimony } \\
\text { Fit Indices }\end{array}$} & Parsimony Ratio (PRATIO) & \multirow{3}{*}{ Range Value from 0 to 1} & 0,780 & Model 'fit' or suitable well \\
\hline & & $\begin{array}{l}\text { Parsimony Normed Fit } \\
\text { Index( PNFI) }\end{array}$ & & 0,710 & Model 'fit' or suitable well \\
\hline & & $\begin{array}{l}\text { Parsimony Comparative Fit } \\
\text { Index ( PCFI) }\end{array}$ & & 0,765 & Model 'fit' or suitable well \\
\hline & & $\begin{array}{l}\text { Root Mean Square Error } \\
\text { Approximation } \\
\text { ( RMSEA) }\end{array}$ & Value $<0,05$ & 0,045 & Model 'fit' or suitable well \\
\hline & & $\begin{array}{l}\text { Aikake Information } \\
\text { Criterion } \\
\text { (AIC/BCC/BIC/CAIC) }\end{array}$ & \multirow{2}{*}{$\begin{array}{l}\text { The value smaller if } \\
\text { compared with value of } \\
\text { saturated model and } \\
\text { independence model) }\end{array}$} & 156,946 & $\begin{array}{l}\text { Model 'fit' or suitable well } \\
\text { (The value smaller if } \\
\text { compared with value of } \\
\text { saturated model and } \\
\text { independence model) }\end{array}$ \\
\hline & & $\begin{array}{l}\text { Expected Cross-Validation } \\
\text { Index ( ECVI) }\end{array}$ & & 1,266 & $\begin{array}{l}\text { Model 'fit' or suitable well } \\
\text { (The value smaller if } \\
\text { compared with value of } \\
\text { saturated model and } \\
\text { independence model) }\end{array}$ \\
\hline & & Hoetler & Under 200 & $\begin{array}{r}128 \\
\text { (significant } \\
\text { of } 5 \% \text { ) \& } \\
142 \\
\text { (significant } \\
\text { of } 1 \% \text { ) } \\
\end{array}$ & Model 'fit' or suitable well \\
\hline
\end{tabular}

Source of Data: Result of data processing, 2012

\section{Validity Test Variable (confirmatory factor analysis) and Reliability Test Variable}

The validity tests of all loading factors where each indicator has a value $>0.5$ with $\mathrm{p}=0.000$ smaller than $\alpha=0,05$. It indicates that all indicators and questions that are used are statistically valid in measuring the developmental variables of coastal area $(\mathrm{X})$, where value of loading factor $\mathrm{X} 1.1=0,88 ; \mathrm{X} 1.2=0,92 ; \mathrm{X} 1.3=0,88$; the environmental change (Y1), where value of loading factor $\mathrm{Y} 1.1=0,85 ; \mathrm{Y} 1.2=0,87$; and adaptive behavior (Y2) where value of loading factor $\mathrm{Y} 2.1=0,89 ; \mathrm{Y} 2.2=0,88$, and traditional fishermen welfare $(\mathrm{Z})$ where value of loading factor $\mathrm{Z1}=0,79 ; \mathrm{Z} 2=0,58 ; \mathrm{Z3}=0,77 ; \mathrm{Z} 4=0,83 ; \mathrm{Z} 5=0,79 ; \mathrm{Z} 6=0,56 ; \mathrm{Z} 7=0,63$. Therefore, the indicators with question items that are used are able to explain the existing variables.

From the reliability test of variables, it shows that the development variable of coastal development area (X1) gives a composite reliability (CR) value of 0.732 ; the variable of environmental change (Y1) has a CR value of 0.795 ; and the variable of adaptive behavior (Y2) has a CR value of 0.808 . The results show that all variables have a composite reliability (CR) higher than the cut off value of 0.05 . Therefore, it can be concluded that all variables are reliable.

The effect of coastal area development, environmental change, and adaptive behavior on the welfare of traditional fishermen in Manado Bay

During the fit test from all hypothetical models, then it is changed the arrangement of the variable component of the measurement model that has been done by determining the independent variable and dependent variable. The testing results of hypothetical model with Structural Equation Modeling that is shown in Figure 2 is as follows:

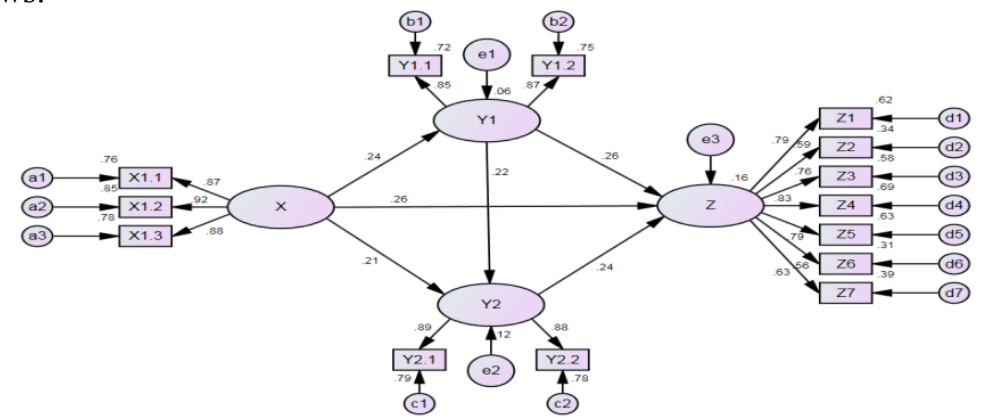

Fig. 2. Structural Equation Modeling of the Relationship between Exogenous Latent Variables and Endogenous Latent Variable 
Explanation:

$\mathrm{X}=$ Coastal Development:

X1.1= Capability Development Program; X1.2=Income Improvement Program; X3= Infrastructure Availability

$\mathrm{Y} 1=$ Environmental Change: $\mathrm{Y} 1.1=$ Quality of Environment; $\mathrm{Y} 1.2=$ Environmental Services

$\mathrm{Y} 2=$ Adaptive Behavior: $\mathrm{Y} 2.1=$ Functional Adaptation; $\mathrm{Y} 2.2=$ Process Adaptation

$Z=$ Traditional Fishermen Welfare: $Z 1=$ Income; $Z 2=$ Saving; $Z 3=$ Expenditure; $Z 4=$ Boat and Equipments

Occupation; Z5=Housing; Z6= Education; Z7=Health.e1,e2,e3=error;

$\mathrm{a} 1, \mathrm{a} 2, \mathrm{a} 3, \mathrm{~b} 1, \mathrm{~b} 2, \mathrm{c} 1, \mathrm{c} 2, \mathrm{~d} 1, \mathrm{~d} 2, \mathrm{~d} 3, \mathrm{~d} 4, \mathrm{~d} 5, \mathrm{~d} 6, \mathrm{~d} 7=$ Determinant Coefficient of Indicators.

Figure 2 shows the results of structural equation modeling (SEM) complete with exogenous and endogenous latent variables. It was arranged based on the existing theory and obtained path coefficient. Moreover, it is interpreted for each path coefficient in the structural equation modeling and the related path coefficients provide the answer for the hypotheses of the research modeling as follows:

$$
\begin{aligned}
& \mathrm{Y} 1=0,24 \mathrm{X} \\
& \mathrm{Y} 2=0,21 \mathrm{X}+0,22 \mathrm{Y} 1 \\
& \mathrm{Z}=0,26 \mathrm{X}+0,26 \mathrm{Y} 1+0,24 \mathrm{Y} 2
\end{aligned}
$$

Therefore, the hypothesis that "the development of the coastal area, environmental change, and adaptive behavior influence the traditional fishermen welfare" can be accepted. The structural equation modeling can be interpreted that welfare improvement for the traditional fishermen has occurred as long as the development of the coastal area considers the traditional fishermen's needs; and their environment such that; the environmental change will be better support their work as fishermen, and is supported by their adaptive behavior in adjusting to the environmental change. However, if the coastal development is done without considering the fishermen's needs and their environment, the environmental change well worsen (negative impact) and not support the work needs of the traditional fishermen; and their adaptive behavior well not adjust beneficially with the environmental change, then the welfare of the traditional fishermen cannot be improved.

Coastal development is a change process to improve community welfare including that of the traditional fishermen. The usage of coastal and marine resources that do not fulfill integrated and sustainable development principles will influence the ecosystem, and will disturb the economic life, social, and cultural pattern of the environment. This is caused by the coastal and marine area and the ecosystem order is also closely related with the upland, either through river stream, run off or ground water, or with various human activities. The results show that coastal development, environmental change, and adaptive behavior have influenced positively and significantly to the welfare of traditional fishermen in the Manado Bay. Scholars point out that economic diversification of the coastal area is more effective then developing only one economic sector [11] [12].

The results also show some important factors in improving the traditional fishermen's welfare of which firstly is boat ownership and also for the supporting equipment in order to adapt to the environmental change; secondly, is improvement in the capability improvement of the traditional fishermen in preparing themselves to face their new environment. A reality that has occurred is that the traditional fishermen struggle to improve because they have difficulty in getting alternative jobs, because of their limited skills. Although they have high motivation to adapt to survive, but motivation alone is not enough to improve their welfare. Thirdly, programs of capability improvement do not always achieve intended goals that is they do not meet the traditional fishermen needs; including infrastructure facilities, such as, mooring at some places being inadequate and insufficient. The testing of the path coefficients was presented in Figure 2 and the structural equation modeling is presented in Table 2 .

Table 2. Result Test of Path Coefficient

\begin{tabular}{|c|c|c|c|c|c|}
\hline No & Variables & $\begin{array}{c}\text { Path } \\
\text { Coefficient }\end{array}$ & $\begin{array}{c}\text { Critical } \\
\text { Ratio } \\
(\mathbf{C R})\end{array}$ & Prob. & Explanation \\
\hline 1 & Coastal Development (X) With Environmental Change \\
$(Y 1)$ & 0.238 & 2.318 & 0.020 & Significant \\
\hline 2 & Coastal Development (X) With Adaptive Behavior (Y2) & 0.214 & 2.216 & 0.034 & Significant \\
\hline 3 & Coastal Development (X) with Traditional Fishermen \\
Welfare (Z) & 0.264 & 2.617 & 0.009 & Significant \\
\hline 4 & Environmental Change (Y1) with Adaptive Behavior (Y2) & 0.224 & 2.103 & 0.035 & Significant \\
\hline 5 & $\begin{array}{c}\text { Environmental Change (Y1) with Traditional Fishermen } \\
\text { Welfare (Z) }\end{array}$ & 0.261 & 2.419 & 0.016 & Significant \\
\hline 6 & Adaptive Behavior (Y2) with Traditional Fishermen \\
Welfare (Z) & 0.237 & 2.240 & 0.025 & Significant \\
\hline
\end{tabular}

Source of Data: Result of data processing, $2012 ; p<0,05$ 
The interpretation of each direct effect of these path coefficients as shown in Table 2 can be explained as follows:

\section{The Effect of Coastal Development Related to the Environmental Change of Traditional Fishermen}

Table 2 shows that there is empirical evidence to accept the hypothesis that coastal development affect the environmental change of the traditional fishermen. The positive path coefficient indicates that the variable of coastal development effect positively the environmental change of the traditional fishermen. It can be said that each increase in development activity in the coastal area, will result in change to the traditional fishermen's environment of 0.238 or $23.8 \%$ and vice versa.

There are several programs activities have been instituted in the coastal area of Manado Bay such as: the capability development program, the income improvement program, and the availability of infrastructure, including reclamation each of which significantly changes the traditional fishermen's environment. Environmental change that impacts in the positive way include change to the environmental quality such as the presence of wider opportunities to do alternative work for these traditional fishermen, the availability of infrastructure around their environment that supports environmental services such as tourism, protection of fishermen's residences from the wave danger, and decrease in the area of slum.

However, coastal development also brought with it negative change to the physical quality of the sea. The sea become dirty and polluted because of trash/industrial waste introduced from development of the boulevard area and nearby residential areas, moreover it damaged coral, caused insufficient boat mooring, made fishing locations become further away, and the more modern fishing (pajeko). Negative environmental change such as the sea being dirty and polluted by development was expressed by $76.8 \%$ or 96 persons of the respondents as demonstrated in the following comments:

"Formerly, it is clean, but now very dirty, maybe because of the many population and they throw to the sea".

"There is bad smell at the mooring, because many waste discharge over there from the business area".

"Many trash and oil from the machine shop that flow to the sea, so the sea become dirtier".

Furthermore, change occurred in environmental services, that is $86.4 \%$ or 108 respondents stated that the "soma dampar" (the traditional fish catching system) can no longer be practiced, in some areas, because of change in the infrastructure. Fortunately, however, there are still certain places in the Manado Bay where catching fish through the "soma dampar" system has not been curtailed because so far there is no big deterioration at these locations.

Statute No. 32 of the year 2009, article 1 sub section 1 about Protection and Management of the Environment, states that the environment is a unity of space with all things, forces, situation, creatures, including human beings and their behaviors, that can influence nature itself, life viability, and the welfare of humans and other creatures. The fishing yield of the fishermen depends on the physical environment it being clean and not polluted. Because of contamination of the physical environment including damaged coral and consequence loss of land for fish breeding this has caused a decrease in the fishing yield of the traditional Manadonese fishermen. This has not been offset by the availability of new marine tourism activities such that this industry can be able to support the traditional fishermen's welfare. Scholar shows that there are various negative impacts of the Suramadu Bridge construction in Surabaya for the local fishermen. The bridge construction lead decrease in the fishing yield, change in social values, skill change, and decrease in the income of fishermen's household. Moreover, the root problem of coral damage caused by community activities include: (1) the poverty of community and the absence of alternative livelihood, (2) ignorance and unawareness of the local community and user about protection to the coastal environment and its resources; (3) weak law enforcement, (4) governmental policy that does not give adequate attention to managing natural systems and the environmental quality of coastal and marine areas [13].

\section{The Effect of Coastal Development to the Adaptive Behavior of Traditional Fishermen}

Table 2 shows that there is empirical evidence to accept the hypothesis that coastal development influence the adaptive behavior of traditional fishermen. The positive path coefficient has indicated that coastal development influences positively the adaptive behavior of traditional fishermen. Moreover, it can be said that each increasing of development activity at the coastal area, will improve the adaptive behavior of traditional fishermen by 0.034 or $3.4 \%$ and vice versa.

Coastal development in Manado Bay has brought significant influence onto fishermen activities and to make the adaptations in their life as stated by $88.8 \%$ or 111 respondents, who indicated that they had tried to adapt their fishing systems and methods to accommodate change. While $76.8 \%$ or 96 respondents stated that they had tried to adapt to do alternative work to fulfill their life needs, however, only $12 \%$ or 15 persons that do not do other alternative work with reason do not have other skills. Interview results with the source persons found that the alternative work that is done by these traditional fishermen include: farming, laborer, servant in 
the restaurant, net marker, parker, driver, trader, and stall. Considering their low education level (52\%) or 65 of the respondents did not graduate from elementary schools/or did not attend school at all, and that they do not have special skills; this has placed them in low skill jobs. Although they have high motivation to adapt with the alternative opportunities made available by development in the coastal area, but they lack the skills to adapt and take advantage of the opportunities.

The respondents comments about improvement in the capability of traditional fishermen through skill training, shows that $69.9 \%$ or 87 respondents agreed that appropriate skill training improves their ability. Adding or improving skills such as how to catch using modern method, understanding how to properly manage business activities, and gaining other knowledge all can improve the fishermen's welfare. The research indicated that these traditional fishermen are not prepared well by government to face the consequences and deal with coastal development. One respondent expressed their opinion about inadequate preparation of traditional fishermen in facing the coastal development at the Manado Bay as follows:

"the coastal development is not good for me, because although it has been given other opportunities beside profession as the fishermen, but mostly the fishermen have no other skills to do the other work".

\section{The Effect of Coastal Development to the Welfare of Traditional Fishermen}

Table 2 shows there are enough empirical evidence to accept the hypothesis that coastal development influences the welfare of traditional fishermen. The positive path coefficient indicated that coastal development (X) influence positively the welfare of traditional fishermen (Z). It can be said that each increase in development activity in the coastal area, will increase the welfare of traditional fishermen by 0.264 or $26.4 \%$ and vice versa.

Coastal development has brought opportunities for the coastal communities, including for traditional fishermen especially in obtaining alternative jobs that can be undertaken during the unseasonal or poor times and when not catching fish. Scholar found that business improvement and other work opportunities bring a positive influence for the fishermen and associated communities, thus improving their income. Various opportunities and new work opened up for the traditional fishermen, therefore some respondents were able to do alternative work during down periods and when the catch fish is poor. This is also improved if supported by various existing facilities such as cheap business areas, sufficient infrastructure, no slum anymore around their residential area [14]. The research has shown income information as follows: that $2.4 \%$ or 3 persons have average income of $\mathrm{Rp} 1,000,000<$ Income $<$ Rp. 2,000,000, and $0.8 \%$ or 1 person has an income of $\mathrm{Rp}$. $2,000,000<$ Income $<$ Rp. $3,000,000$, and $0.8 \%$ or 1 person has income of $>$ Rp. 3,000,000. These results show that some fishermen have a high enough income as a consequence of having other alternative jobs such as being a craftsman, having a stall, and being fish collector traders as was stated by one respondent as follows:

"Because this trading area is close to the residential area, then it is useful for me, because the obtained fishes can be sold to big fish restaurant and our children work at the business area easily"

However, the research also shows that many of the traditional fishermen in the coastal area of Manado Bay still have low incomes and welfare. Seen from their position the research shows that the income level for these respondents is as follows; (59.74\%) or 74 persons only have an average income $<\mathrm{Rp}$. 500,000 per month, and $36.8 \%$ or 46 persons have an average income of Rp. $500,000<$ Income $<$ Rp. $1,000,000$. The research shows that there is a lack of preparation in facing the challenge of change, such as the lack of supporting infrastructure for fishermen's business, the absence of soft loans, and the lack of skill, low education, inappropriate aid objectives that do not address the fishermen's real needs, and the physical change of the decline in the sea's cleanness. Of the respondents $(72 \%)$ or 90 persons revealed that the development of coastal areas does not support the fishermen business, as explained by some source persons as follows:

"The business area development is not good to support the fishermen business, because the business area has damaged the mooring, has damaged the corals for fish, has damaged the environment, because the trash are thrown to the sea".

"It is not good, because with the business area, the fishermen should go to the sea 3-4 hours from the shore, because the place for fish eat has been damaged because of reclamation, and fish that previously can be caught easily today became difficult to catch".

\section{The Effect of Environmental Change on the Adaptive Behavior of Traditional Fishermen}

There is enough empirical evidence to accept the hypothesis that environmental change influences traditional fishermen's adaptive behavior (Table 2). The positive path coefficient has shown that environmental change (Y1) has influenced positively the adaptive behavior of traditional fishermen (Y2). It can be said that each increase in environmental change in the coastal area, will increase the adaptive behavior of traditional fishermen by 0.224 or $22.4 \%$ and vice versa.

The presence of coastal area development has changed the traditional fishermen's environment in both positive and negative ways. These affects have been physical, social and economic in the coastal area of Manado Bay, and these development changes have significantly influenced the traditional fishermen's adaptive 
behavior. Almost all respondents (91.2\%) or 114 persons are still fishing (they have not changed to another profession). There was ecological change and social system change such as transformation of land use along the coastal area, that as a consequence the communities around these coastal areas has changed dramatically, and that therefore, the commercial fishermen have adapted and used various strategies to get resource allocations and environmental services [15]. The research shows that almost all respondents $(88 \%)$ or 111 persons tried to adapt their fishing technique and methods in order to be suitable with the changed conditions as explained by some sources as follows:

"I do for survival, because no other skill that I can do"

"What thing to eat if not to go to the sea"

"There many burden and only my skills that I have, just hobby, and this is our work from generation to generation"

Furthermore, a significant majority respondents $(76.8 \%)$ or 96 fishermen want the government to assist in improving, wish to adapt to change, and to try other alternative work, such as farming, waitress in restaurant, working as a waiters in a restaurant, net maker, parker, driver, collector trader, and running a stall. Only $12 \%$ or 15 persons that do not do alternative work with their reason being that they have not got other skills.

\section{The Effect of Environmental Change on the Welfare of Traditional Fishermen}

Environmental change influences the traditional fishermen's welfare (Table 2). The positive path coefficient has shown that environmental change (Y1) has influenced positively the welfare of traditional fishermen (Z). It can be said that each increase in environmental change for the traditional fishermen in the coastal area, will increase the welfare of traditional fishermen by 0.261 or $26.1 \%$ and vice versa.

It can be seen that presence of positive environmental change such as the availability of various opportunities, job vacancies and other business opportunities can widely improve the fishermen's traditional welfare. Although there are $2.4 \%$ or 3 respondents that have incomes of Rp. $1,000,000<$ Income $<$ Rp. $2,000,000$, and $0.8 \%$ or 1 respondent who has an average income of Rp.2,000,000<Income $<$ Rp. $3,000,000$, and $0.8 \%$ or 1 respondent who has an average income $>$ Rp. 3,000,000. The research results show that they have earned a high income because of various adaptations they have made as a consequence of environmental change, by having alternative businesses, and by adapting their fishing methods such as using a raft. However, negative environmental change, such as, dirty and polluted physical environment and community waste, the fishing by 'soma dampar' at certain places can no longer be done, because of shore reclamation. In spite of that, with the owned facilities of the traditional fishermen that is insufficient, the insufficient mooring, aids that are not appropriate in objective, difficult work capital to obtain, cause the low welfare of the traditional fishermen at Manado Bay.

\section{The Effect of Adaptive Behavior on the Welfare of Traditional Fishermen}

Table 2 shows that adaptive behavior influences the traditional fishermen's welfare. The positive path coefficient has shown that adaptive behavior (Y2) has influenced positively the welfare of traditional fishermen (Z). It can be said that each increase in adaptive behavior of the traditional fishermen in the coastal area, will increase the welfare of traditional fishermen by 0.237 or $23.37 \%$ and vice versa.

It can be seen from the adaptive behavior that the traditional fishermen are able to adapt to their environmental conditions, and then there is welfare improvement. The research results show that where the traditional fishermen are able to adapt their behavior to their changed environment then they are able to improve their welfare, even though there are only $2.4 \%$ or 3 persons that have an average income per month Rp. $1,000,000<$ Income $<$ Rp. $2,000,000$, and only $0.8 \%$ or 1 person that has an income of Rp 2,000,000 $<$ Income $<$ Rp. $3,000,000$, and $0.8 \%$ or 1 respondent that has an income of $>$ Rp. 3,000,000. The results show that they have high income because they have adapted their behavior to their changed environment, by adopting alternative businesses, such as being collector traders, and other business opportunities.

\section{The Indirect Effect between the Research Variables}

Indirect effect occurred between the exogenous latent variables of coastal development, environmental change of the traditional fishermen, and their adaptive behavior, to the endogenous latent variables of the traditional fishermen's welfare. This indirect influence between the exogenous and endogenous variables is depicted as follows:

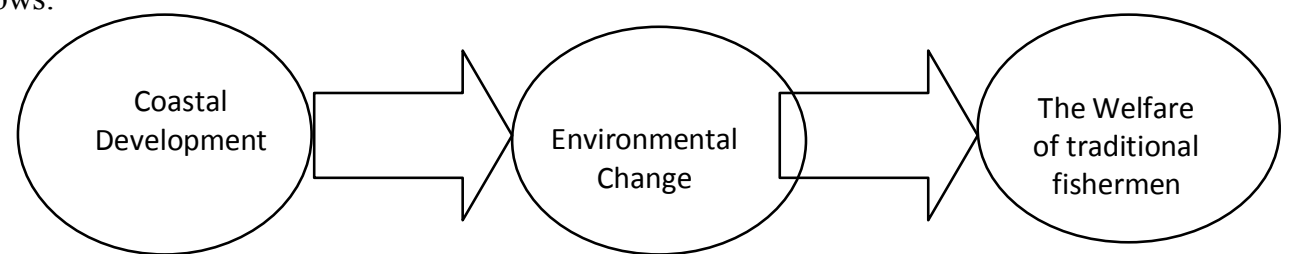

Figure 3. The effect of coastal development on the traditional fishermen's welfare As a result of environmental change to the traditional fishermen 
Figure 3 shows that the indirect effect between coastal development to the welfare of the traditional fishermen through environmental change, obtained an indirect effect coefficient of +0.126 . Because the direct effect of coastal development to the welfare of traditional fishermen, and environmental change to the welfare of traditional fishermen were both significant, then it can be concluded that there is a significant indirect relationship and effect between coastal development and the welfare of traditional fishermen through the environmental change. Also, because the indirect effect coefficient is positive indicates that, the more that coastal development considers and takes account of the traditional fishermen needs, then the better is the traditional fishermen's welfare, as long as the environmental change becomes better. Thus, the environmental change variable is the intervening variable between coastal development and the traditional fishermen's welfare. The coastal sensitivity to the environmental changes has been reported by numerous authors [16] [17] [18].

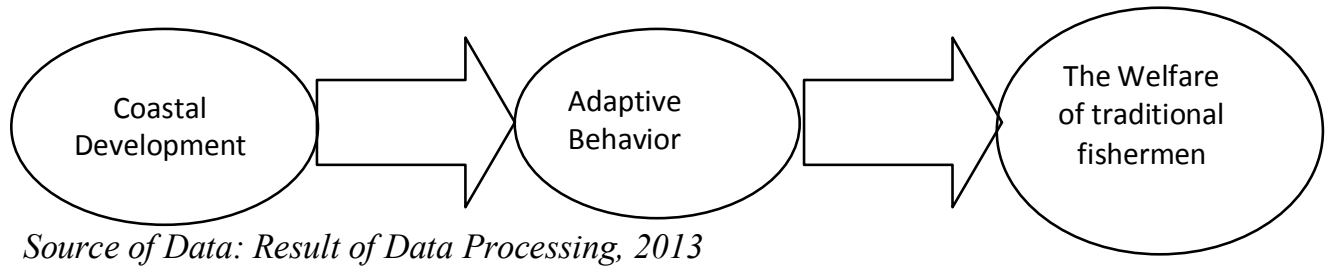

Figure 4. The effect of coastal development on the traditional fishermen's welfare As a result of the adaptive behavior of the traditional fishermen

Figure 4 show that the indirect effect between coastal developments on the traditional fishermen's welfare through their adaptive behavior obtained an indirect effect coefficient of +0.054 . Because the direct effect of coastal development to the traditional fishermen's welfare, and the adaptive behavior to the traditional fishermen welfare were both significant, then it can be concluded that there is a presence of a significant indirect effect between coastal development and the traditional fishermen's welfare through the adaptive behavior of the traditional fishermen. Because the coefficient of the indirect effect is positive then this indicates that the more that coastal development considers the fishermen needs, then the better their welfare, as long as the fishermen adaptive behavior becomes better. Therefore, the adaptive behavior variable is the intervening variable between the effect of coastal development and the traditional fishermen's welfare.

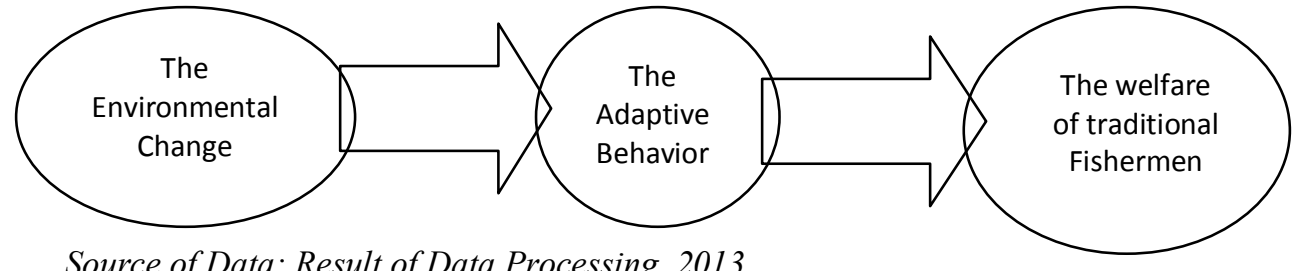

Source of Data: Result of Data Processing, 2013

Figure 5. The effect of environmental change on the traditional fishermen's welfare As a result of the adaptive behavior of the traditional fishermen

Figure 5 show that the indirect effect between environmental change and the traditional fishermen's welfare through adaptive behavior obtained an indirect effect coefficient of +0.053 . Because the direct effect of environmental change to the traditional fishermen welfare, and the adaptive behavior to the traditional fishermen's welfare were both significant, then it can be concluded that, there is a presence of a significant indirect effect between environmental change and the welfare of traditional fishermen through the adaptive behavior of the traditional fishermen. Because this indirect effect is positive, it indicates that the better the environmental change considers the traditional fishermen needs, then the better the traditional fishermen's welfare, as long as the fishermen adaptive behavior becomes better. Therefore, the adaptive behavior variable of the traditional fishermen is the intervening variable between environmental change and the traditional fishermen's welfare.

Directly or indirectly, environmental change for these traditional fishermen (either positive or negative) makes them try to do adapt either their fishing methods, along with trying to find new or alternative business opportunities, in order to improve their welfare. It is found found that environmental management, social economics conditions, and institutions, partially and simultaneously have a positive relation with fishpond production. However, the research found also that the physical condition and shore environment have experienced the land use changes scenario of coastal Manado (locally called Rencana Tata Ruang Wilayah) [19]. Conversely, the social, economic condition of local society of the coastal area is less proper, the institution less stable and environmental management still weak. It is indicated caused by the low community welfare or less prosper. Along with this research, the research results show the same thing, that is environmental change for the traditional fishermen (positive or negative) provides wide opportunities to get new and alternative income. 
However, because of their low skill base and education and although they have high motivation to adapt, too many fishermen are still unable to improve their welfare. The co-management of coastal by involving local fisherman therefore considered important [20] [21]

\section{The Total Effect Between the Research Variables}

The total effect of the exogenous latent variables of coastal development, environmental change, and adaptive behavior to the endogenous latent variable of traditional fishermen's welfare is depicted as follows:

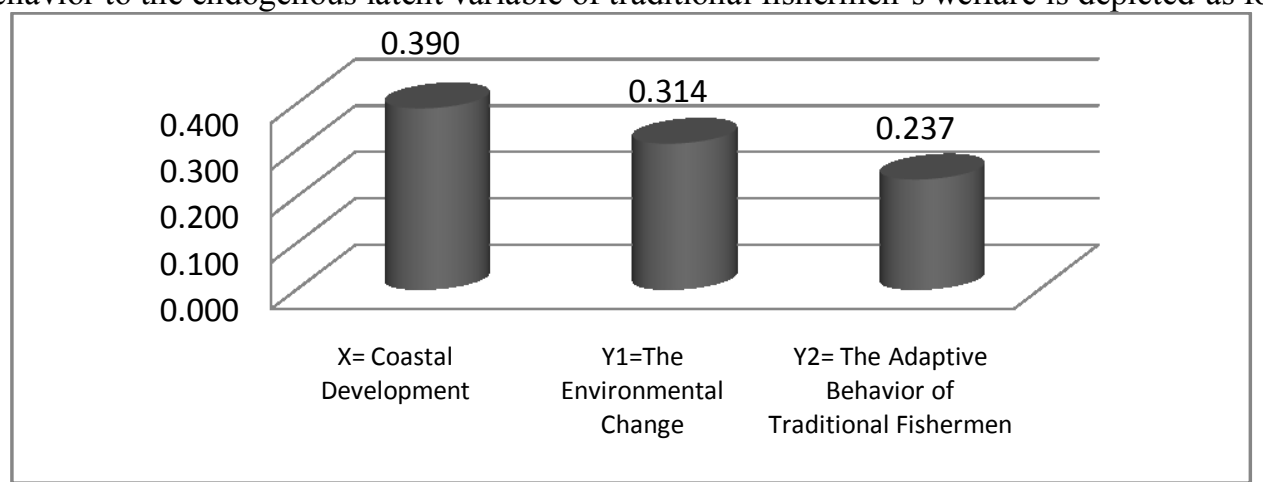

Source of Data: Result of Data Processing, 2013

Figure 6. The Total Effect of Coastal Development, Environmental Change, and Adaptive Behavior on The Traditional Fishermen's Welfare

Figure 6 show that coastal development has a total effect on the traditional fishermen's welfare, either by improving the fishermen's capability, fishermen's income improvement, or giving infrastructure. It shows that the presence of coastal development is able to improve the traditional fishermen welfare by 0.39 or $39 \%$. Moreover, various opportunities for traditional fishermen to improve their welfare has been opened widely and provided them with the opportunities for them to improve their welfare. Figure 7 show that environmental change of traditional fishermen is the second biggest total effect impacting on the traditional fishermen's welfare of 0.341 or $34.1 \%$. Thus the environmental quality and the availability of environmental services for the traditional fishermen of the Manado Bay affect their livelihood. Also of importance is the availability of adequate and appropriate infrastructure around the residential area of the fishermen along with various facilities that provide them opportunities to improve their welfare. However, it cannot be avoided that environmental change, such as pollution that impacts negatively on the sea's physical environment also influences the traditional fishermen welfare. Furthermore, the third variable of the adaptive behavior of the traditional fishermen has the third total effect of 0.237 or $23.7 \%$ for the traditional fishermen's welfare.

Finally, it can be stated that coastal development that is done integrally and sustainably will produce less imbalance, and moreover will bring positive and significant benefits for economic growth that will provide an even and fair improvement for the traditional fishermen's welfare. Therefore, coastal resources that are supported and can be well maintained, and the ecosystem and development sustainability can be run in balance [20] [22].

\section{CONCLUSION}

It is concluded that, firstly, coastal development in Manado Bay, change in the local environment, and consequent adaptive behavior positively and significantly influence the welfare of traditional Manadonese fishermen either partially or simultaneously, directly or indirectly, and totally. Secondly, that change in the local environment has resulted in both positive and negative impacts on the lives of the traditional fishermen in the coastal area of Manado Bay. Thirdly, that coastal development in Manado Bay has not given adequate attention the needs of the traditional fishermen. Finally, that the highest level of the fishermen's adaptive behavior is not balanced with the level of the traditional fishermen's capability. Some recommendation for enhancing and improving the traditional fishermen's welfare in the coastal area of Manado Bay are as follows:

1) Any development of the coast in Manado Bay needs to be linked and in line with the traditional fishermen's need;

2) Any development need to be focused on and improving those environmental which cause positive impacts on the lives and welfare of traditional fishermen.

3) Environmental change which causes negative impacts for the traditional fishermen need to be minimized if not entirely eliminated;

4) There need to be programs of empowerment that can strengthen and improve the adaptive behavior of the traditional fishermen in facing environmental change properly. 


\section{ACKNOWLEDGEMENT}

The author would like to thank to the following institutions: The Directorate of Higher Education and Manado State Polytechnic for funding and supporting the study, and the following people for helpful comments and suggestions on an earlier draft of this article: DR Bambang, O Widjarnako, Busli \& Ketsya, John Moore, Clarita PIJ, Willem Pomantow, Nancy Mandey, Sonya Lentey, Ivonne Mandang and Freddy Hafner, and Christine Karambut.

[1] S.B. Olsen and P. Christie, 2000. What are we learning from tropical coastal management experiences? Coastal Management, 28, $5-18$.

[2] C. Béné, When fishery rhymes with poverty: a first step beyond the old paradigm on poverty in small-scale fisheries. World Development, 31(6), 2003, 949-975.

[3] M. Weinstein and D.J. Reed, Sustainable coastal development: the dual mandate and a recommendation for "commerce managed areas", Restoration Ecology, 13(1), 2005, 174-182.

[4] M. Kusumaatmadja and E.R. Agoes, Rights Over Natural Resources: The Indonesian Experience. Centre for Archipelago, Law and Development Studies - Alumni Publisher, Bandung, 2002.

[5] K. Nomura, A perspective on education for sustainable development: Historical development of environmental education in Indonesia. International Journal of Educational Development, 29(6), 2009, 621-627.

[6] P. Brunt and P. Courtney, Host perceptions of sociocultural impacts. Annals of Tourism Research, 26(3),1999, 493-515.

[7] W.N. Adger, Social and ecological resilience: are they related? Progress in Human Geography, 24(3), 2000, 347-364.

[8] L. Hakim, Soemarno, S.K. Hong, Challenges for conserving biodiversity and developing sustainable island tourism in North Sulawesi Province, Indonesia. Journal of Ecology and Field Biology, 35(2): 2012, 61-71.

[9] K.S. Andaria, Marsoedi, D. Arfiati, L. Hakim, Soemarno, Stakeholder Analysis for Coastal Tourism Development in Bangka Island, North Sulawesi Indonesia. J. Basic. Appl. Sci. Res., 3(1), 2013, 1043-1050.

[10] BPS Manado, Statistik Kota Manado, Provinsi Sulawesi Utara, Manado, 2012.

[11] T. Chopin, A.H. Buschmann, C. Halling, M. Troell, N. Kautsky, A. Neori, G.P. Kraemer, J.A. Zertuche-González, C. Yarish and C. Neefus, Integrating seaweeds into marine aquaculture systems: a key toward sustainability. Journal of Phycology, 37(6), 2001, 975986.

[12] T. AbdeL-Latif, S.T. Ramadan and A.M. Galal, Egyptian coastal regions development through economic diversity for its coastal cities. HBRC Journal, 8(3), 2012, 252-262.

[13] R. Wijayanti and A. Subianto, Analisis dampak pembangunan Jembatan Suramadu bagi masyarakat nelayan: Studi eksploratif pada aspek social, ekonomi, Kelembagaan di Kelurahan tambak Wedi, Kenjeran Surabaya. Jurnal Aplikasi Manajemen, 10(2), 2008, 96112 .

[14] A. Suherman and A. Dault, Analisis dampak sosial ekonomi keberadaan Pelabuhan Perikanan Nusantara (PPN) Brondong Lamongan Jawa Timur, Jurnal Saintek Perikanan, 5(1), 2009, 25 - 30.

[15] J. Endter-Wada and S.P. Keenan, Adaptation by long-term Commercial Fishing Families in California Bight: Coping with changing coastal ecological and social systems. Human Organization, 64 (3), 2005, 225-239.

[16] J.D. Hansom, Coastal sensitivity to environmental change: a view from the beach. Catena, 42(2), 2001, 291-305.

[17] J. Davenport, and J.L. Davenport, The impact of tourism and personal leisure transport on coastal environments: a review. Estuarine, Coastal and Shelf Science, 67(1): 2006, 280-292.

[18] D.M. Bilkovic and M.M. Roggero, Effects of coastal development on nearshore estuarine nekton communities. Marine Ecology Progress Series no. $358-27,2008$

[19] R.B. Hastuti, Korelasional antara manajemen lingkungan, sosial-ekonomi dan kelembagaan dengan produksi tambak Di wilayah Kota Semarang, Jurnal Litbang Provinsi Jawa Tengah, 7(2), 2009, 177-183.

[20] M. Makino and H. Matsuda, Co-management in Japanese coastal fisheries: institutional features and transaction costs. Marine Policy, 29(5), 2005, 441-450.

[21] T.A. Branch, R. Hilborn, A.C. Haynie, G. Fay, L. Flynn, J. Griffiths, K.N. Marshall, J.K. Randall, J.M. Scheuerell, E.J. Ward and M. Young, Fleet dynamics and fishermen behavior: lessons for fisheries managers. Canadian Journal of Fisheries and Aquatic Sciences, 63(7), 2006, 1647-1668.

[22] D.W. Cash, W.C. Clark, F. Alcock, N.M. Dickson, N. Eckley, D.H. Guston, J. Jager and R.B. Mitchell, Knowledge systems for sustainable development. Proceedings of the National Academy of Sciences, 100(14), 2003, 8086-8091. 